\title{
Skarbowość Rzeczypospolitej lat 1587-1697 (Stan badań, źródla i postulaty)
}

\section{Staatsfinanzen Polens in den Jahren 1587-1697 (Stand der Forschung, Quellen und Postulate)}

1. Wstęp. 2. Organizacja systemu skarbowego. 3. System podatkowy. 4. Syluacja finansowa Rzeczypospolitej. 5. Skarb nadworny. 6. Dalsze postulaty badawcze.

1. Einleitung. 2. Organisation der Staatsfinanzen. 3. Steuersystem. 4. Finanzsituation Polens. 5. Hofschatz. 6. Weitere Postulate.

1. Badania nad skarbowością staropolską rozpoczął Adolf Pawiński, opublikowaną przed ponad stu laty pracą dotyczącą panowania Stefana Batorego'. Był to okres ogromnie ważny dla kształtowania się nowożytnych struktur finansowych Rzeczypospolitej Obojga Narodów. Monografia A. Pawińskiego stała się podstawą i punktem wyjścia dla późniejszych historyków, zajmujących się finansami Polski w epoce nowożytnej. System skarbowy nowożytnego państwa polskiego ukształtował się pod koniec epoki jagiellońskiej, w pewnej mierze jako efekt egzekucji dóbr i praw, i aż do roku 1717 - niewiele się zmienil. Modyfikacje wprowadzone decyzją sejmu niemego $z$ tego roku nie usprawniły go niestety; przeciwnie - uniemożliwiły reformę do końca panowania Wettynów. Moje rozważania koncentrują się na trzech problemach: (1) organizacji systemu skarbowego i (2) rodzajach świadczeń na rzecz państwa oraz (3) sytuacji finansowej Rzeczypospolitej.

2. W Rzeczypospolitej istniały dwie kasy państwowe, z których jedna nazwana skarbem kwarcianym lub rawskim, powstala $w$ wyniku reform ruchu egzekucyjnego, fukcjonowala tylko w Koronie, nie mając na Litwie swego odpowiednika. Skarb ten stanowił ewenement w ówczesnej Europie, bowiem jego dochody stanowily wyłącznie wpływy z dóbr królewskich, czyli

A. Pa wiński, Skarbowość w Polsce i jej dzieje za Stefana Batorego, Warszawa 1881 
$\mathrm{z}$ domeny. $\mathrm{W}$ epoce królów elekcyjnych były to dobra państwowe, których władca był tylko dożywotnim użytkownikiem, w zakresie ustalonym ustawami sejmowymi, czyli konstytucjami, bez moźliwości przekazania ich potomstwu. Sama kwarta była jedynym stałym dochodem państwa, przeznaczonym na obronę kresów pohudniowo-wschodnich ${ }^{2}$. Zasady funkcjonowania skarbu kwarcianego zostały przedstawione na podstawie aktów normatywnych oraz prywatnej korespondencji osób liczących się w życiu państwowym ówczesnej Rzeczypospolitej, w jednym $\mathrm{z}$ rozdziałów monografii o skarbowości za Zygmunta III Wazy ${ }^{3}$, następnie za Władysława IV $^{4}$ oraz $w$ drugiej połowie XVII w. ${ }^{5} \mathrm{Z}$ początkiem panowania na tronie polskim drugiego Wazy opodatkowano dodatkowo królewszczyzny, tym razem nie tylko koronne, lecz także litewskie; obciążono je tak zwaną drugą kwartą i przeznaczono na artylerię. Kwarta litewska wpływała do kasy państwowej razem $z$ innymi podatkami, bo nie stworzono dla niej oddzielnego skarbu.

Drugą kasę skarbu państwowego nazywano skarbem pospolitym lub publicznym. W państwie polsko-litewskim były dwa: koronny i litewski, i do nich wpływały podatki uchwalone przez sejmy na określone potrzeby, przeważnie militarne. Oba miały charakter okresowy, niestały i oba podlegały władzy podskarbiego wielkiego koronnego albo litewskiego, pełniących funkcję ministra skarbu z nominacji królewskiej. Dysponujemy pełnym wykazem podskarbich koronnych ${ }^{7}$ i litewskich ${ }^{8}$ tego okresu - większość z nich ma swoje biogramy w Polskim slowniku biograficznym ${ }^{9}$.

${ }^{2}$ Problemy związane z kwartą naświetliła w trzech artykułach A. S u ch en i - G rabow ska: Losy egzekucji dobr w Koronie w latach 1574--1650, „Kwartalnik Historyczny” [dalej: KH] 1973, t. LXXX, z. 1, s. 3-19; Próba aukcji dochodów z dóbr domeny królewskiej w świetle lustracji z lat 1615-1620, „Przegląd Historyczny” [dalej: PH], 1967, t. LVIVII, z. 2, s. 221-242; Walka o wymiar $i$ przeznaczenie kwarty $w$ końcu XVI w. I na poczq̨tku XVII w., PH 1965, t. LIV, z. 1, s. 2445.

${ }^{3}$ A. Filipczak-K ocur, Skarb koronny za Zygmunta III Wazy, Opole 1985, s. 12-16.

${ }^{4}$ A. Filipczak-K ocur, Skarb koronny za Wladyslawa IV, Opole, 1983.

${ }^{5}$ R. R ybarski, Skarb i pieniądz za Jana Kazimierza, Michala Korybuta i Jana III, Warszawa 1939, s. 161-170.

${ }^{6}$ A. Filipczak-K oc u r, Skarb litewski za pierwszych dwu Wazów, 1587-1648, Wroclaw 1994, s. 40-43; R. R y barski, Skarb i pieniqdz..., s. 170-172.

${ }^{7}$ Urzędnicy centralni i nadworni Polski XIV-XVIII wieku. Spisy, red. A. Gąsiorowski, Kórnik 1992, s. 125-126.

${ }^{8}$ Urzędnicy centralni $i$ dostojnicy Wielkiego Księtwa Litewskiego XIV-XVIII wieku. Spisy, oprac. H. Lulewicz, A. Rachuba, Kórnik 1994, s. 156-158.

${ }^{9}$ Funkcję podskarbiego w Koronie pełniło w tym okresie 13 podskarbich. Do tej pory opracowano biogramy $10 \mathrm{z}$ nich. Podaje je w kolejności sprawowania przez nich funkcji podskarbiego: Jan Dulski (K. Le pszy, Dulski Jan, [w:] Polski slownik biograficzny [dalej: PSB], t. V, 1939-1946, s. 461-462); Jan Firlej (K. L e p s z y, Firlej Jan, PSB, t. VII, 1948-1958, s. 1-7); Mikołaj Daniłowicz (K. Piwarski, Danilowicz Mikolaj, PSB, t. IV, 1938, s. 416-417); Hermolaus Ligęza (H. Kow alsk a, Hermolaus Ligeza, PSB, t. XVII, 1972, s. 315-316); Jan Mikołaj Daniłowicz (W. Hejnos z, Danilowicz Jan Mikolaj, PSB, t. IV, 1938, s. 415-416); 
Wiadomo, jakie kompetencje posiadali podskarbiowie, ponieważ określały je konstytucje sejmowe. Można ponadto ocenić pracę poszczególnych podskarbich, zwłaszcza tych z pierwszej połowy XVII w. W kilku przypadkach pomocne są wytworzone przez nich źródła: obfita korespondencja Jana Firle$\mathrm{ja}^{10}$, Jarosza Wolłowicza ${ }^{11}$ i Krzysztofa Naruszewicza ${ }^{12}$. Znacznie uboższa jest zachowana korespondencja pozostalych podskarbich. $\mathrm{Z}$ urzędu podskarbiego rezygnowano, zwłaszcza w pierwszej połowie XVII w., częściej niż z innych urzędów ministerialnych. $Z 13$ podskarbich koronnych pięciu zrezygnowało ze swego urzędu. $Z$ pełnieniem tej funkcji wiązały się uciążliwe obowiązki, nierzadko przykrości; był to urząd pod ciągłą kontrolą publiczną - sejmową i sejmikową. Na podskarbich ciążyła ponadto odpowiedzialność materialna, która przechodziła także na ich spadkobierców. Ale z urzędem wiązały się nie tylko odpowiedzialne obowiązki. Przed ministrem finansów otwieraly się możliwości bogacenia się drogą legalną, chociaż niektórzy z nich, jak Bogusław Leszczyński czy Jan Andrzej Morsztyn, bogacili się również w sposób zdecydowanie nielegalny ${ }^{13}$. Podskarbi zarabiał przede wszystkim na tzw. ,rękawicznym", czyli na gratyfikacjach od dzierżawców różnych podatków ${ }^{14}$. Znane mi

Bogusław Leszczyński (W. Dworzaczek, Leszczyński Boguslaw, PSB, t. XVII, 1972, s. 107-111); Jan Kazimierz Krasiński (A. Przybós, Krasiński Jan Kazimierz, PSB, t. XV, 1970, s. 179-180); Jan Andrzej Morsztyn (A. Prz y boś, Morsztyn Jan Andrzej, PSB, t. XXI, 1976, s. 809-815); Marek Matczyński, (H. K ot a r s k i, Matczyński Marek, PSB, t. XX, 1975, s. 175-176); Hieronim August Lubomirski (J. W i m m e r, Hieronim Augustyn Lubomirski, PSB, t. XVIII, 1973, s. 11-14). Nie mają biogramów tylko trzej podskarbiowie w omawianym okresie: Baltazar Stanisławski, Stanisław Warszycki i Marcin Zamoyski. Na Litwie w tym czasie funkcje podskarbiego sprawowało 12 osób, z których 7 ma swoje biogramy: Dymitr Halecki (O. Ha leck i, Halecki Dymitr, PSB, t. III, 1937, s. 247-249); Krzysztof Naruszewicz (T. Wa silewski, Naruszewicz Krzysztof, PSB, t. XXII, 1977, s. 565-567); Stefan Pac (W. Cza pli ński, Stefan Pac, PSB, t. XXIV, 1979, s. 748-749); Mikolaj Kiszka (T. W a silewsk i, Kiszka Mikolaj, PSB, t. XII, 1966-67, s. 513-514); Wincenty Aleksander Gosiewski (A. Przybós, Gosiewski (Gasiewski) Wincenty Aleksander, PSB, t. VIII, 1959-1960, s. 343-347); Hieronim Kryszpin Kirszensztein ( $T$. W a silew ski, Kryszpin-Kirszensztein Hieronim, PSB, t. XV, 1970, s. 497-498); Benedykt Pawel Sapieha (A. R a chu ba, Sapieha Benedykt Pawel, PSB, t. XXXIV, 1992-1993, s. 583-591). W okresie podskarbiostwa Wincentego Gosiewskiego z powodu jego nieobecności powierzano 3 razy administrację skarbu innym osobom: Aleksandrowi Krzysztofowi Naruszewiczowi (A. R a c h u b a, Naruszewicz Aleksander Krzysztof, PSB, t. XXII, 1977, s. 561-564); Krzysztofowi Zygmuntowi Pacowi (PSB, t. XXIV, 1979, s. 411) i Adamowi Maciejowi Sakowiczowi (M. Nagielski, PSB, t. XXXIV, s. 334-339). Nie mają biogramów nastepujący podskarbiowie litewscy: Teodor Skumin Tyszkiewicz, Andrzej Zawisza, Jarosz Wołłowicz, Mikołaj Tryzna oraz Gedeon Michał Tryzna.

${ }^{10}$ Biblioteka PAN w Kórniku, 1400: Biblioteka Muzeum im. Książąl Czartoryskich w Krakowie, 98.

"Archiwum Główne Akt Dawnych w Warszawie [dalej: AGAD], Archiwum Radziwiłłowskie [dalej: AR), 19766.

12 AGAD, AR V, 10262.

${ }^{13}$ E. Deiches, Koniec Morstina, Kraków 1894.

14 R. R y barski, Skarb i pieniqdz..., s. 35-39. 
źródła pozwalają stwierdzić, że zysk podskarbiego wynosił połowę dochodów Rzeczypospolitej z dzierżawy szelężnego, cla nowo podwyższonego czy monopolium tabacznego ${ }^{15}$. Możliwości zysku podskarbich zwiększyły się znacznie w drugiej połowie XVII w., kiedy wprowadzono wiele nowych podatków pośrednich, ściąganych za pośrednictwem dzierżawców. Podskarbiowie, dysponując państwowymi pieniędzmi, mieli ogromny wpływ na wojsko, a przez to i na politykę, której bez pieniędzy uprawiać nie sposób.

Warto by ustalić, jakie znaczenie miało podskarbiostwo dla tworzenia fakcji magnackich, zwłaszcza na Litwie w drugiej połowie XVII w. Benedykt Paweł Sapieha rządził właściwie Litwą na spółkę ze swoim bratem Kazimierzem, hetmanem wielkim. Podskarbi przewodniczył zawsze Trybunałowi Skarbowemu, hetman - komisjom skarbowo-wojskowym. Obaj ci urzędnicy sprawowali kontrolę nad dwoma najważniejszymi bodaj resortami życia państwowego: praktycznie dysponowali finansami i wojskiem.

Dokładniej można poznać terenową administrację skarbową, którą tworzyli poborcy i dzierżawcy podatkowi, tylko jeśli szczegółowo przebadamy zachowane akta sejmikowe, księgi grodzkie, księgi trybunału skarbowego i komisji skarbowo-wojskowych. Informacje na ten temat zamieścili wszyscy autorzy monografii sejmikowych ${ }^{16}$, jak i prac, dotyczących samorządu szlacheckiego $w$ poszczególnych województwach. $Z$ pewnością potrzebne jest opracowanie samorządu szlacheckiego w poszczególnych województwach; badania tego rodzaju przeprowadzono już dla Małopolski ${ }^{17}$.

Terenowa administracja skarbowa - podobnie jak podatki - miała charakter okresowy. Tworzono ją dla każdego podatku oddzielnie, dla doraźnych potrzeb. Na tym między innymi, polegała jej słabość, jak również mała skuteczność. Wspierały ją różne sądy: sądy grodzkie, Trybunał Główny, powołany jednorazowo $w 1591$ r. najwyższy sąd skarbowy połączony z komisją do zapłaty wojsku, czy nawet sąd sejmowy. Od 1613 r. powoływano co jakiś czas Trybunal Skarbowy oddzielnie dla Korony i Litwy. Kwestie związane z Trybunałem Skarbowym Koronnym opracował Leon Babiński ${ }^{18}$,

${ }^{15}$ AGAD, AR II, 1578. Sa to wykazy sporządzone w skarbie litewskim po sejmie koronacyjnym w $1676 \mathrm{r}$. Z czopowego, cla i monopolium tabacznego skarb miał otrzymac $349000 \mathrm{zl}$, podskarbi Benedykt Sapieha - $176900 \mathrm{zl}$, dzierżawcy - $252900 \mathrm{zl}$, z szelężnego miało wpłynąc do skarbu litewskiego $610200 \mathrm{zl}$, dla podskarbiego przeznaczono $333250 \mathrm{zl}$, dla dzierżawców - 434200 zł (R. R y ba rski, Skarb i pieniq̨dz..., s. 36-39).

${ }^{16}$ Nie widzę potrzeby wymienienia $w$ tym miejscu wszystkich monografii sejmikowych znanych doskonale badaczom epoki. Warto może tylko przypomnieć syntetyczną pracę Marii Rhode, która przyblizyła problemy w okresie pierwszych siedmiu bezkrólewii, w tym także podatkowe, niemieckiemu czytelnikowi (M. R hod e, Ein Königreich ohne König. Der Kleinpolnische Adel in sieben Interregna, Wiesbaden, 1997).

${ }^{17}$ A. Lity íski, Szlachecki samorzqd gospodarczy w Malopolsce (1606-1717), Katowice 1974; W. K r i g g e is e n, Samorzqd szlachecki w Malopolsce w latach 1669-1717, Warszawa 1989.

${ }^{18}$ L. B a biński, Trybunal Skarbowy Radomski, Warszawa 1928. 
a uzupełnił $w$ formie polemiki Józef Rafacz $^{19}$. Oba opracowania mają charakter prawno-historyczny. Monografię o Trybunale Skarbowym Litewskim napisal w 1936 r. Leonas Šbunas ${ }^{20}$, ale bez znajomości ksiąg trybunalskich przechowywanych obecnie w Wilnie i w Mińsku. Przeprowadzona przeze mnie kwerenda pozwoliła na opracowanie problemów prawnych związanych z funkcjonowaniem Litewskiego Trybunału Skarbowego na podstawie zachowanych tam archiwaliów ${ }^{21}$. J. Rafacz przesunąl datę powstania pierwszego Trybunału Skarbowego na 1591 r., kiedy powołano sąd skarbowy najwyższej instancji, połączony $\mathrm{z}$ komisją wojskową.

Jednak w świadomości ówczesnych pierwszym Trybunałem Skarbowym był trybunal powolany na sejmie w 1613 r.; nazywano go najczęściej radomskim, chociaż nie zawsze odbywal się w Radomiu. Dla Litwinów właśnie Trybunał Radomski był synonimem Trybunału Skarbowego, stąd i litewski nazywali niekiedy też radomskim. Sądownictwo skarbowe miało na celu ściągnięcie zaległych pođatków. Podlegały mu osoby, które miały do czynienia z pieniędzmi państwowymi oraz należacymi do skarbu królewskiego. W 1659 r. powołano dodatkowo wojewódzkie i powiatowe sądy skarbowe, które także miały charakter okresowy.

W XVII w. powoływano często komisje wojskowe do płacenia wojsku, również skonfederowanemu. Było to wsparciem dla słabo rozbudowanej administracji skarbowej, a także pomocą dla władz wojskowych. Ich kompetencje określała każdorazowo odpowiednia konstytucja sejmowa: zazwyczaj miały za zadanie sprawdzenia faktycznej liczby wojska, ustalenie należnego mu żołdu, dokonanie zapłaty, ewentualne pertraktacje $\mathrm{z}$ wojskiem o jej odroczenie, jeśli skarb nie dysponowal potrzebną gotówką. Na tych komisjach odbywały się także sądy hetmańskie. Od $1634 \mathrm{r}$. - zarówno w Koronie, jak i na Litwie - przez połączenie Trybunału Skarbowego z komisją wojskową zmieniły charakter, stając się sądem skarbowym ostatniej instancji. Funkcjonowały zatem dwa niezależne od siebie Trybunaly Skarbowe. Litewskie komisje wojskowo-skarbowe doczekały się niedawno opracowania ${ }^{22}$; brakuje natomiast analogicznego studium dotyczącego komisji koronnych. Kolejnym zatem postulatem badawczym jest przygotownie studium prawno-historycznego na temat komisji skarbowo-wojskowych w Koronie. Źródła ich dotyczące, z czasów Wladysława IV znajdują się, między innymi, we Wroclawiu ${ }^{23}$. Dokładna kwerenda także w innych archiwach $\mathrm{i}$ bibliotekach krajowych może przynieśc ciekawe rezultaty.

19 J. R a f a c z, Trybunal Skarbowy Koronny, KH 1924, t. XXXVIII, s. 413-455.

${ }^{20}$ L. Ša bun a s, Didžiosios Lietuvos Kunigaikštysts, Iždo Tribunolas (1613-1763), Kaunas 1936.

${ }^{21}$ A. F il i pczak-K oc u r, Litewski Trybunal Skarbowy (1591-1717), „Studia z Dziejów Państwa i Prawa Polskiego" 2002, t. VII, s. 183-209.

${ }_{22}$ A. Filipczak-Kocur, Litewskie komisje wojskowo-skarbowe w XVII wieku, KH 2002, R. CIX, s. 97-117.

${ }^{23}$ Biblioteka Uniwersytetu Wrockawskiego, Steinwehr, II, III. 
3. Stosunkowo najlepiej znane są zasady naliczania poszczególnych podatków, zarówno koronnych, jak i litewskich. Zasady te określane były w konstytucjach i uniwersalach poborowych, a drukowane w Volumina legum. Choć najobszerniej omówił ten problem R. Rybarski (poświęcając mu ponad 260 stron), to wcześniej odpowiednie rozdziały znalazły się w pracy A. Pawińskiego, a następnie jeszcze $w$ kolejnych monografiach $\mathrm{i}$ artykułach ${ }^{24}$. O powinnościach wojennych Żydów pisal Maurycy Horn ${ }^{25}$, a świadczenia duchowieństwa na rzecz państwa znane są $z$ dwu monografii Henryka Karbownika ${ }^{26}$. Tę stosunkowo obszerną już wiedzę można jeszcze wzbogacić o informacje dotyczące funkcjonowania systemu podatkowego $w$ praktyce. Źródla na ten temat w odniesieniu do skarbu litewskiego znajdują się, między innymi, w Wilnie; są to trudne do usystematyzowania, różnorodne informacje, a wśród nich korespondencja podskarbich $\mathrm{z}$ dzierżawcami rozmaitych podatków ${ }^{27}$. Mnóstwo tego rodzaju wiadomości zawierają księgi grodzkie ${ }^{28}$.

4. Znane są dochody i wydatki skarbu koronnego oraz litewskiego za pierwszych dwu Wazów na tronie polskim. Dokładna kwerenda w archiwach polskich, litewskich, we Lwowie oraz w Szwecji pozwoliła ustalić, czym dysponowało państwo polsko-litewskie do końca panowania Władysława IV $^{29}$.

${ }^{24}$ Litewski historyk $\mathrm{K}$. A viž onis w swojej pracy o szlachcie w życiu politycznym Litwy epoki Wazów, w rozdziale zatytułowanym: Zaniedbanie potrzeb skarbu państwowego zajął się również praktyczną stroną funkcjonowania systemu finansowego (Bajori valstybiniame Lietuvos gyvenime Važu laikais, Kaunas 1940, wyd. II, Roma 1975). A. Fili pczak-K ocu r, Podatki litewskie $w$ świetle uchwal sejmowych, 1587-1632, „Acta Universitatis Wratislaviensis" 1988, Historia, 66, s. 216-228; tejże, Podatki litewskie w swietle uchwal sejmowych, 1632-1648, „Zeszyty Wyższej Szkoły Pedagogicznej w Opolu” 1990, Historia, 26, s. 155-164.

${ }^{25}$ M. Horn, Powinności wojenne Żydów Rzeczypospolitej w XVI i XVII wieku, Warszawa 1978.

${ }^{26} \mathrm{H}$. K a r bownik, Ciężary stanu duchownego $w$ Polsce na rzecz panstwa od roku 1381 do polowy XVII wieku, Lublin 1980; te nże, Obciqżenia stanu duchownego w Polsce na rzecz panstwa od polowy XVII w. do 1795 r., Lublin 1984.

${ }^{27}$ Lietuvos Moksly Akademijos Biblioteka, F. 273/1464.

${ }^{28}$ Vilniaus Universiteto Biblioteka: księgi wiłkomierskie (F-7, 13 888, k. 385-86; 13887, nr 26), żmudzkie (F-2,3,/14455, k. 100-102), poniewieskie (F-7 8/15241, s. 748-750, 6/15239, k. 614, 4/15193, k. 138). Protestacja Litwinów przeciwko podatkom w 1603 r. znajduje się w Bibliotece Narodowej w Wilnie (Lietuvos Nacionaliné Martyno Mažvydo Biblioteka, PR, 728, k. 105).

${ }^{29} \mathrm{~J}$. Wi mmer, Wojsko $i$ skarb Rzeczypospolitej u schylku XVI $i$ w pierwszej polowie XVII wieku, „Studia i Materiały do Historii Wojskowości” 1968, t. XIV, cz. 1, s. 3-91; A. Filipczak-Kocur, Skarb Koronny za Zygmunta III Wazy, Opole 1985; A. Tyla, Lietuva ir Livonija XVI a. Pabaigoje - XVII a. Pradžioje, Vilnius 1986; A. Fili p czak - K ocu r, Finanse Rzeczypospolitej w latach 1587-1632, „Zeszyty Naukowe Wyższej Szkoły Pedagogicznej w Opolu" 1988, Historia XXVI, s. 27-48; t e jż e, Skarb koronny za Wladyslawa IV 1632-1648, Opole 1991; A. Tyla, Lietuvos Didžiosios Kunigaikštystes iždas 1600-1632, „Lietuvos TSR Moksl Akademijos Darbai" 1986, A serija, t. I (94); A. Fili pc zak-K o cu r, Skarb litewski 
Dla drugiej połowy XVII w. znany jest tylko stan kasy koronnej z zachowanych niemal w komplecie rachunków podskarbich nazywanych ówcześnie rachunkami sejmowymi. Zawarte $w$ nich informacje uporządkował i zamieścil w odpowiednich tabelach R. Rybarski.

Gdy chodzi o skarb litewski, dysponował on tylko jednym rozliczeniem Benedykta Pawła Sapiehy na sejmie w $1678 \mathrm{r}^{30}$ Zatem znajomość finansów Wielkiego Księstwa Litewskiego do końca lat trzydziestych, kiedy wyszła drukiem praca R. Rybarskiego, można określić jako nikłą. Stan tej niewiedzy utrzymal się przez kolejne kilkadziesiąt lat. Dopiero w latach osiemdziesiątych XX w. zmienily go prace litewskiego historyka Antanasa Tyli oraz moje, ale tylko w odniesieniu do pierwszej polowy XVII w. Gdy chodzi o druga połową tego stulecia, do tej pory ukazal się tylko artykuł Andrzeja Rachuby o rozliczeniu wojska na komisji wojskowo-skarbowej w $1650 \mathrm{r}^{31}$ oraz mój o finansach litewskich w latach 1647-1649. Począwszy od sejmu konwokacyjnego w 1648 r. do końca panowania Jana III Sobieskiego 25 sejmów uchwaliło podatki dla Litwy, a jeden raz - w 1665 r. na konwokacji grodzieńskiej, a także raz ex senatus consilium w 1687 r.

Tabela: Wykaz sejmów i litewskich rachunków skarbowych dotyczących ich uchwał w latach 1648-1695

\begin{tabular}{|r|l|c|l|}
\hline Lp. & \multicolumn{1}{|c|}{ Data sejmu } & $\begin{array}{c}\text { Uchwała } \\
\text { podatkowa* }\end{array}$ & \multicolumn{1}{|c|}{ Źródła } \\
\hline 1 & 1648 konwokacyjny & + & MI, 124 \\
2 & 1648 elekcyjny & - & MI, 124 \\
3 & 1649 koronacyjny & + & MI, 124 \\
4 & $1649 / 50$ & + & brak żódeł \\
5 & 1650 & + & NGAB, F. 1737, op. 1, 24 \\
6 & 1652 & - & \\
7 & 1652 & + & ML, 128 \\
\hline
\end{tabular}

$\overline{z a}$ pierwszych dwu Wazów. 1587-1648, Wrocław 1994; te jże, Między drugim a trzecim Wazq na tronie polskim. Finanse litewskie w latach 1647-1649, [w:] Czlowiek i Kościól w dziejach, Opole 1999, s. 201-208; tejże, Skarb litewski po śmierci Wladyslawa IV, „Miscellanea Historico-Archivistica" 2001, t. XII, s. 67-74. Próbę przyblizenia skarbowości polskiej historykom zagranicznym stanowią następujące prace: J. Rutkowskiego, Les bases economiques des partages de l'ancienne Pologne, „Revue d'Histoire Moderne” 1932, new ser., 4, s. 363-389; A. Fili pczak-K ocu r, Das Finanzwesen der Adelsrepublik unter Sigismund III, 1587-1632, „Acta Poloniae Historica" 1991, t. 64/4, s. 5-26; t ejże, Poland-Lithuania before Partition, [w:] The reise of the foscal state in Europe c. 1200-1815, ed. R. Bonney, Oxford University Press 1999, s. 443-479; tejze, The Lithuanian treasury under the reign of first two Vasas 1587-1648, [w:] State finance: The european experience, c. 1200-1800, Conference 5-8 July 1997

${ }^{30}$ R. R y bar ski, Skarb i pieniqdz..., s. 524, 534. Autor nie podal sygnatury; jest AGAD, AR II, 1578, s. 96-114.

${ }_{31}$ A. R a c hu b a, Komisja wileńska 1650 roku, Europa Orientalis, Toruń 1996, s. 279-288. 
Tabela (cd.)

\begin{tabular}{|c|c|c|c|}
\hline Lp. & Data sejmu & $\begin{array}{c}\text { Uchwała } \\
\text { podatkowa* }\end{array}$ & Źródła \\
\hline 8 & 1653 & + & brak źródeł \\
\hline 9 & 1654 & - & \\
\hline 10 & 1654 & + & brak źródeł \\
\hline 11 & 1655 & + & brak źródeł \\
\hline 12 & 1658 & + & MI, 131 \\
\hline 13 & 1659 & + & AWAK, 34 \\
\hline 14 & 1661 & + & brak źródeł \\
\hline 15 & 1662 & + & LVIA, 3410,3114 \\
\hline 16 & $1664 / 65$ & - & \\
\hline 17 & 1665 & - & \\
\hline 18 & 1666 & - & \\
\hline 19 & 1666 & - & \\
\hline 20 & 1667 & + & LVIA, 3418 \\
\hline 21 & 1668 & - & \\
\hline 22 & 1668 & - & \\
\hline 23 & 1668 konwokacyjny & + & LVIA, 3439 \\
\hline 24 & 1669 elekcyjny & + & LVIA, 3439 \\
\hline 25 & 1669 koronacyjny & - & \\
\hline 26 & 1670 & - & \\
\hline 27 & 1670 & + & LVIA, 3439 \\
\hline 28 & 1672 & - & \\
\hline 29 & 1672 & - & \\
\hline 30 & 1673 & + & LVIA, 3444,3420 \\
\hline 31 & 1674 konwokacyjny & + & LVIA, 3444,3420 \\
\hline 32 & 1674 elekcyjny & - & \\
\hline 33 & 1676 koronacyjny & + & AGAD, AR, II, 1578 \\
\hline 34 & 1677 & + & $\mathrm{ADAG}, \mathrm{AR}, \mathrm{II}, 1578$ \\
\hline 35 & $1678 / 79$ & + & LVIA, $3416,3452,3421$ \\
\hline 36 & 1681 & + & 年, \\
\hline 37 & 1683 & + & LVIA, 3452 \\
\hline 38 & 1685 & + & LVIA, 3454 \\
\hline 39 & 1688 & - & \\
\hline 40 & $1688 / 89$ & - & \\
\hline 41 & 1690 & + & LVIA, 3459 \\
\hline 42 & $1692 / 93$ & - & \\
\hline 43 & 1693 & - & \\
\hline 44 & 1695 & - & \\
\hline
\end{tabular}

* Objaśnienie: + uchwała podatkowa; - brak uchwały.

Wykaz sejmów od śmierci Władysława IV do końca panowania Jana III oraz zachowanej dla nich dokumentacji skarbowej zawiera tabela, która wymaga pewnego komentarza. Dochody i wydatki skarbu litewskiego $\mathrm{z}$ podatków uchwalonych $\mathrm{w} 1647 \mathrm{r}$. oraz na konwokacji warszawskiej w 1648 r. są wyszczególnione w kwicie wydanym podskarbiemu Gedeonowi 
Michałowi Tryźnie na sejmie koronacyjnym Jana Kazimierza w $1649 \mathrm{r}^{32}$ Kolejne wpływy i wydatki $\mathrm{z}$ podatków uchwalonych na sejmie elekcyjnym i koronacyjnym ujęte są w pokwitowaniu dla tegoż podskarbiego. Otrzymał je na sejmie w 1649/50. Oba kwity wpisano do księgi metryki mniejszej podkanclerzego Kazimierza Leona Sapiehy. Pod Zborowem niektóre $z$ ksiąg zabranych tam przez podkanclerza zostały zniszczone, ale część wydobyto $z$ błota $i$ przepisano, o czym $w$ jednej $z$ nich zamieszczono informacje ${ }^{33}$. $Z$ komisji wileńskiej odbytej w $1650 \mathrm{r}$. wiadomo o dochodach i wydatkach do połowy tego roku, a stan skarbu do drugiego sejmu w 1652 r. jest udokumentowany sumariuszem znajdującym się $w$ Mińsku $^{34}$. Dochody i wydatki do następnego sejmu w Brześciu w 1653 r. znajdują w kwicie Wincentego Korwina Gosiewskiego ${ }^{35}$. Kolejne pokwitowanie pochodzi dopiero z 1659 r. - dla administratora skarbu, kanclerza wielkiego, Krzysztofa Paca. Administrowal on skarbem od końca $1658 \mathrm{r}$. do kwietnia $1659 \mathrm{r}^{36}$ Zarząd skarbu przejął po nim Adam Maciej Sakowicz na okres 11 kwietnia 1659 - 23 marca $1662 \mathrm{r}$. Jego rozliczenie do czerwca $1661 \mathrm{r}$. przyjęto na sejmie w $1661 \mathrm{r}^{37}$ Wpływy $\mathrm{i}$ wydatki $\mathrm{z}$ podatków uchwalonych $\mathrm{w} 1662 \mathrm{r}$., przedstawione $w$ Wilnie na komisji 20 marca 1671 r., zawierają dwie $\mathrm{księgi}^{38}$. Po 1662 r., najbliższy sejm, który uchwalił podatki, odbył się dopiero w 1667 r. Wcześniej, bo w 1665 r. podatki uchwaliła konwokacja grodzieńska ${ }^{39}$. Rozliczenie dochodów i wydatków z lat 1662 oraz 1665 zawiera sumariusz rachunków Hieronima Krzyszpina Kirszenszteina. Rozliczenie to przygotowano na sejm w $1668 \mathrm{r}$., potem na sejm koronacyjny w 1669 r. Ponieważ oba zerwano, do zatwierdzenia doszło dopiero na drugim sejmie w $1670 \mathrm{r}^{40}$ Istnieje ponadto rozliczenie $\mathrm{z}$ wojskiem za okres

${ }^{32}$ F. 389, 124 [dalej: ML, 124), s. 390-393.

${ }^{33} \mathrm{ML}, 124$, s. $312 \mathrm{i} \mathrm{n}$.

${ }^{34}$ Nacjonalny Gistaryčny Archiu Balarusi, F. 1737, op. 1, 24, s. 304-346.

${ }^{35} \mathrm{ML}, 128$.

${ }^{36} \mathrm{ML}, 131$, s. 785. Pokwitowanie nosi datę $29 \mathrm{~V} 1659$, chociaż sejm skończył się 2 V 1659 r. K. Pac rozliczył się w kwietniu 1659 r. (AWAK, t. 34, s. 441).

${ }^{37}$ AWAK, t. 34, s. 441-541. Wpływy zatwierdzono 4 czerwca, wydatki - 8 czerwca.

${ }_{38}$ LVIA, 3410, 3414. Księga o sygnaturze 3410 jest rewersałem księgi o sygnaturze 3414. 22 I 1682 r. oddano tę księge skarbnemu Kazimierzowi Skorobohatemu. Stwierdzono zgodność oryginah $z$ rewersałem. Rewersał odebrał Piotr Kublicki - podczaszy połocki. Księga oryginalna (3414) jest obecnie uszkodzona; brak pierwszych 22 stron. W księdze tej znajduje się ponadto pokwitowanie dla zmarłego Gabriela Karola Kimbara, skarbnego. Notka w tej księdze jest następująca: Te ksiege liczebnq zeszlego pana Gabriela Kimbara skarbnego WKs.L. dobrodzieja ojca mojego podlug nakazu dekretu komisyjej grodzieŕskiej w 1681 r. odprawowanej, oddalem do rak jm. Pana Andrzeja Skorobohatego, skarbnego WKs.L., pisarza grodzkiego trockiego $i$ rewersal $z$ tej ksiegi $z$ samym oryginalem zunifikowany $z$ podpisem jm. Pana skarbnego WKs.L. odebralem. Piotr Kublicki, podczaszy plocki.

39 Uchwała konwokacji grodzieńskiej, LVIA, 4680. Ponadto w ML, 132, s. 1044-1058.

${ }^{40}$ LVIA, 3418. 
od 10 września 1663 r. do 10 marca 1667 r. na komisji w Wilnie w 1667 r. ${ }^{41}$ Wpływy i wydatki z podatków uchwalonych na konwokacji warszawskiej w 1668 r., na sejmie elekcyjnym w 1669 r. oraz na sejmie w 1670 r. zawiera kolejny rachunek podskarbiego Kirszenszteina zatwierdzony na sejmie koronacyjnym 31 marca $1676 \mathrm{r}^{42}$ Rozliczenie $\mathrm{z}$ wojskiem na komisji w Wilnie w 1671 r. zostało ujęte w oddzielnym rachunku ${ }^{43}$. Wpływy i wydatki z uchwał sejmu w $1673 \mathrm{r}$. oraz z konwokacji warszawskiej w 1674 zostało przyjęte na sejmie w Grodnie 23 lutego $1679 \mathrm{r}{ }^{44} \mathrm{Na}$ sejmie koronacyjnym 31 marca 1676 r. przyjęto rozliczenie Michała Kazimierza Paca - hetmana wielkiego, i Michała Kazimierza Radziwiłła - podkanclerza, hetmana polnego $\mathrm{z}$ pieniędzy otrzymanych na wojsko biorące udział w kampanii chocimskiej w 1673 r., w kampanii ukraińskiej w 1674 r. oraz w kampanii lwowskiej i podolskiej ${ }^{45}$. Podatki uchwalone na sejmie grodzieńskim w 1678/79 wyszczególniono $w$ dwu rozliczeniach przygotowanych na sejm w $1681 \mathrm{r}$. Zatwierdzono je dopiero w 1683 r., a podpisano 12 maja $1685 \mathrm{r}^{46}$ Ponadto rozliczenie wpływów i wydatków $\mathrm{z}$ uchwał tegoż sejmu, wpłaconych do skarbu po 1681 r. zostało podpisane także w 1685 r., ale dzień wcześniej od poprzedniego, czyli 11 maja $^{47}$. Ta sama księga zawiera również wplywy i wydatki $\mathrm{z}$ podatków uchwalonych w $1683 \mathrm{r}$. Natomiast efekty decyzji finansowych sejmu z 1685 r., także z podatków ex senatus consilium uchwalonych w $1687 \mathrm{r}$. znalazły się w oddzielnej księdze. Zatwierdzono je 31 marca 1689 r. na sejmie ${ }^{48}$. Gdy chodzi o uchwały sejmu z 1690 r., to wiadome są tylko wpływy do 15 października 1692 r.; informacji o wydatkach brak $^{49}$. Natomiast rozliczenie $\mathrm{z}$ otrzymanych zaległości od 1670 r. przygotowane przez podskarbiego Benedykta Sapiehę zostało na sejmie grodzieńskim w $1693 \mathrm{r}$. zatwierdzone ${ }^{50}$.

Z 44 sejmów - od śmierci Władysława IV do ostatniego sejmu za Jana Sobieskiego - 19 nie podjęło decyzji finansowych; niemal wszystkie zostały zerwane. Z 25 uchwal sejmowych znane są efekty finansowe 20. Brak danych tylko o wpływach $\mathrm{i}$ wydatkach $\mathrm{z}$ podatków uchwalonych przez sejmy $\mathrm{z}$ lat 1649/50, 1653 (odbyty w Brześciu), 1654, 1655 oraz 1661. Informacji tych nie odnalazłam $w$ archiwum i bibliotekach wileńskich. Efekty może dać kwerenda w polskich zbiorach rękopiśmiennych. W Ar-

\footnotetext{
${ }^{41}$ LVIA, 4111.

${ }^{42}$ LVIA, 3439.

${ }^{43}$ LVIA, 4114.

4 LVIA, 3444. Brudnopis tego rozliczenia tamże, 3420 .

${ }^{45}$ LVIA, 3437.

${ }^{46}$ LVIA, 3416, 3421.

${ }^{47}$ LVIA, 3452.

${ }^{48}$ LVIA, 3454.

49 LVIA, 3459.

${ }^{\text {so }}$ LVIA, 3429.
} 
chiwum Głównym Akt Dawnych znajdują się ważne dla interesującego mnie okresu źródła, między innymi sumariusz Hieronima Kryszpina Kirszenszteina $z$ podatków uchwalonych na konwokacji w 1668 r., na sejmie elekcyjnym w 1669 r. i 1670 r. Sumariusz ten zostal przygotowany na sejm w 1676 r. $^{51}$ Dwa inne sporządzil podskarbi Benedykt Pawel Sapieha. Jeden z podatków: uchwalonych na sejmach w 1676 i 1677 , przedstawiony na sejmie w $1678 \mathrm{r}^{52}$, drugi - z wplaconych zaleglości od $1670 \mathrm{r}$. Przygotowal je na sejm w $1679 \mathrm{r}^{53}$ Ponadto pod tą samą sygnaturą znajdują się kontrakty dzierżawne na szelężne z 1679 r., z wyszczególnieniem kwot dla poszczególnych województw i powiatów, dekrety komisji wojskowo-skarbowych, rozliczenia $z$ wojskiem, w tym również kontrowersyjne kwestie w 1679 r., dotyczące czwartego miliona należnego wojsku ${ }^{54}$. Problem ten rozpatrywala komisja wojskowoskarbowa w Grodnie, a sprawa ciągnęla się od 1670 r. i była jeszcze aktualna w $1691 \mathrm{r}^{55}$ Wiedzę o archiwaliach skarbowych znajdujących się $w$ archiwach we Lwowie, Kijowie oraz $w$ archiwach polskich wzbogaciła konferencja zorganizowana przez Archiwum Glówne Akt Dawnych w Warszawie, z której materiały zostały opublikowane w "Miscellanea"56.

5. Za Zygmunta III nastąpiło wyraźniejsze oddzielenie skarbu królewskiego od państwowego, usankcjonowane dla Litwy konstytucja z 1589 r., a dla Korony w $1590 \mathrm{r}^{57}$ Zygmunt III wydzielił dobra stołowe uniwersałem z 28 stycznia 1588 r. oraz następnym, miesiąc później. Konstytucja z 1589 r. zatwierdziła tylko stan prawny.

Mniej niż o dochodach skarbu państwowego wiadomo na temat dochodów skarbu nadwornego w XVII w., np. o konkretnych środkach na utrzymanie króla, jego rodziny oraz dworu. Problem tylko z pozoru jest prosty, a jego złożoność już wykazał w swojej sumiennej pracy Władysław Pałucki ${ }^{59}$. Sama

${ }^{51}$ AGAD, ARII, 1578, s. 44-64.

s2 AGAD, AR II, 1578, s. 96-114. Jest to sumariusz wykorzystany przez R. Rybarskiego, podany w wykazie żródel bez sygnatury (R. R ybarski, Skarb i pieniqdz..., s. 524, 534).

${ }_{53}$ AGAD, ARII, 1578, s. 65-93.

s AGAD, ARII, 1578, s. 19-121.

${ }^{55}$ AN Wilno, F. 17--56; F 17-53.

56 Znalazły się tu referaty Leokadii Olechnowicz, Natalii Cariowej, Lubwi Hiscowej, Zofii Wojciechowskiej, Michała Zwierzykowskiego, Janusza Losowskiego, Marka Kunickiego-Gold-Fingera, Tomasza Ciesielskiego oraz Huberta Wajsa (,Miscellanea Historico-Archivistica" 2000 , t. XII).

37 Volumina legum, t. II, wyd. J. Ochryzko, Petersburg 1859 (reprint), s. 289, 312; W. Pałucki, Drogi $i$ bezdroża skarbowości polskiej XVI i pierwszej polowy XVII wieku, s. $149-155,212-217$.

${ }_{58}$ M. Dovna r-Za polskij, Gosudarstvennoe chozzjajstvo Velikogo Kniažestva Litowskogo pri Jagellonach, t. I, Kiev 1901, s. 157-158; A. T yla, XVI-XVIII a. Alytaus ekonomijos valdymas, [w:] Alytas miesto ir apylinki, istorijos bruožai, Vilnius 1989, s. 11.

${ }^{59} \mathrm{~W}$. Pałucki, Drogi i bezdroża.... 
podjęłam się próby obliczenia dochodów i wydatków Zygmunta III $^{60}$, ale wobec skąpo zachowanych źródeł nie można odtworzyć sytuacji finansowej pierwszego Wazy na tronie polskim w catym 45-letnim okresie jego panowania. Nie ulega jednak wątpliwości, że Zygmunt III zapewnił dostatnie, to znaczy na odpowiednim do swojego stanu poziomie, życie sobie i swojej rodzinie.

Jego syn i następca - Wladysław IV uchodzi ciągle za rozrzutnego władcę, chociaż w referacie wygłoszonym na sesji w Krakowie w 2001 r. wykazałam na podstawie źródeł, że król Władysław IV był nie tyle rozrzutny, co ubogi ${ }^{61}$. Ocena taka zostala $w$ pewnej mierze ugruntowana dzięki sumariuszowi rozesłanemu na sejmiki $\mathrm{z}$ prośbą $\mathrm{o}$ zgodę na spłacenie królewskich dhugów. Jeden z takich sumariuszy przedrukował W. Czermak, $\mathrm{z}$ oryginalnym tytułem Króla JM-ci Wladyslawa IV dlugi, które Rzeczpospolita placila $^{62}$. Nieliczni tylko zauważyli, że sumariusz ten zaczyna się od wydatków królewskich na flotę oraz inne potrzeby związane $\mathrm{z}$ przygotowaniem wojny ze Szwecją w 1635 r., oraz że sporą sumę wydał Władysław na gwardię, która $-\mathrm{z}$ wyjątkiem żołnierzy kwarcianych - była jedynym stałym wojskiem w rozległym państwie polsko-litewskim. Może warto by podjąć próbę określenia dochodów i wydatków jego następców. Michał Korybut Wiśniowiecki i Jan III Sobieski znaleźli się w lepszej od nich sytuacji. Mieli własne dobra rodowe; nie musieli liczyć wyłącznie na to, co ofiarowała Rzeczpospolita ${ }^{63}$.

Dla porównania warto przy tym pamiętać o dochodach ministrów i wysokich urzędników. System finansowy państwa umożliwiał bajecznie wysokie gratyfikacje dla podskarbiego, o czym wspomniałam wcześniej. Wszyscy ministrowie i wysocy dygnitarze otrzymywali pensje ze skarbu królewskiego i państwowego. Król dokonywal w pewnym sensie dystrybucji swoich dochodów nie tylko na pensje, lecz także na dyplomację, na utrzymanie zamków, na kampanię sejmową. Król musiał być do pewnego stopnia hojny; zwlaszcza król w państwie elekcyjnym. Pieniądze były narzędziem sprawowania władzy. Można by się zastanowić, czy król mógł utrzymać monarszy prestiż, będąc oszczędny, czy mógł realizować jakiekolwiek koncepcje polityczne, dysponując skromnymi dochodami i nie popadając

${ }^{60}$ A. Filipczak-Kocur, $Z$ dziejów skarbu nadwornego za Zygmunta III Wazy, "Czasopismo Prawno-Historyczne" 1986, t. XXXVIII, z. 1, s. 49-69; 1 ejże, $Z$ dziejów litewskiego skarbu nadwornego za Zygmunta III Wazy, [w:] Miedzy Wschodem a Zachodem. Rzeczpospolita XVI-XVIII w., Warszawa 1993, s. 78-86.

${ }^{61}$ A. Filipczak-K ocur, Rozrzutny czy ubogi król Wladyslaw IV; referat ten ukaże się w tomie materiałów z sesji krakowskiej.

${ }^{62} \mathrm{KH}$ [Lwów] 1897, R. XI, s. 546.

${ }^{63}$ Źródła dotyczące tego problemu znajdują się między innymi w AGAD, Archiwum Skarbu Koronnego, oddz. 1, Rachunki królewskie 305. O finansach pierwszego drugiego Wazy pisal W. Czermak (Na dworze Wladyslawa IV, „Studia Historyczne" [Kraków] 1901, s. 7-36; Z czasów Jana Kazimierza, „Studia historyczne” [Lwów] 1893). 
w długi. Porównanie dochodów królewskich w Polsce $\mathrm{z}$ dochodami ówczesnych monarchów europejskich słusznie uznal Wiktor Czermak za bezcelowe, ponieważ $w$ monarchiach dziedzicznych skarb państwowy był zarazem skarbem królewskim, którym dowolnie dysponował panujący.

6. Przedstawiony w niniejszym szkicu przegląd dorobku skłania do formulowania kolejnych - poza wymienionymi już wcześniej - postulatów badawczych. Przede wszystkim należy opracować $w$ formie monografii skarbowość litewską - od początku panowania Jana Kazimierza do śmierci Jana III Sobieskiego. Zachowane rozliczenia skarbowe, chociaż niekompletne (brak tylko rozliczeń z uchwał pięciu sejmów), umożliwiają realizację takiego zamierzenia. Monografia skarbowości litewskiej drugiej połowy XVII w. pozwoliłaby na rekonstrukcje finansów państwa polsko-litewskiego w XVII w. Mam tu na uwadze monografię o skarbowości w kontekście wydarzeń politycznych, w powiązaniu z funkcjonowaniem sejmików i sejmu. Rozliczenia skarbowe dostarczają istotnych informacji o wysokości dochodów i wydatków państwowych. Nie dostarczaja jednak odpowiedzi na pytania, jak i dlaczego do nich doszło. Monografia o skarbowości powinna właśnie na te pytania odpowiedzieć. Konieczna jest więc kwerenda archiwalna nie tylko wśród źródeł skarbowych, lecz także akt sejmikowych, diariuszy sejmowych oraz korespondencji elity rządzącej ówczesnej Rzeczypospolitej ${ }^{64}$. Potrzebna jest monografia o skarbowości $\mathrm{w}$ powiązaniu $\mathrm{z}$ innymi strukturami, by wyjaśnić, nie tylko jaką kwotą dysponowało państwo, lecz także dlaczego właśnie taką, i jakie czynniki wpływały na taki stan rzeczy. Solidna monografia $R$. Rybarskiego nie wiąże skarbowości z wydarzeniami politycznymi. Potrzebne zatem uzupełnienie jej, polegające na umiejscowieniu podanych przez niego informacji skarbowych w kontekście politycznym i w realiach życia parlamentarnego ówczesnej Rzeczypospolitej. Przy tej okazji niektóre dane zawarte w pracy Rybarskiego można by uzupełnić, inne skorygować.

Potrzebne byłoby także spojrzenie na skarbowość polską w kontekście systemów skarbowych innych państw europejskich, na co pozwalają opublikowane w ostatnim czasie monografie, będące efektem współpracy międzynarodowej ${ }^{65}$. Duże szanse na realizacje takiego zamierzenia stwarza obecnie szeroka możliwość wspólpracy z historykami litewskimi, ukraińskimi i białoruskimi.

${ }^{64}$ Dużą wartość mają opublikowane diariusze i akta sejmowe. Ostatnio ukazała się cenna praca S. Ochman-Staniszewskiej i Z. Staniszewskiego (Sejm Rzeczypospolitej za panowania Jana Kazimierza Wazy, „Acta Universitatis Wratislawiensis” 2002, Historia CXLVII, i. 1-2.

${ }^{65}$ The rise of the fiscal state, ed. R. Bonney; „Economic Systems and State Finance” [Clarendon Press] 1995. 